\title{
Homalocoris punctatus n. sp. and key to the species in the genus (Reduviidae, Microtominae)'
}

\author{
Jenaro Maldonado-Capriles ${ }^{2}$
}

ABSTRACT

Homalocoris punctatus $\mathbf{n}$. $\mathbf{s p}$. is described from Brazil, illustrated, and compared with allied taxa. A key to the six species in the genus is given.

\section{INTRODUCTION}

The members of the small Neotropical subfamily Microtominae (Hammacerinae of authors) are characterized by a very granulate body, abundant setigerous granules, large eyes, multi-pseudosegmented second antennal segment, and somber colors with light areas. From specimens kindly loaned by Dr. T. J. Henry the new species Homalocoris punctatus is described. Type specimens are deposited in the National Museum of Natural History (NMNH) except for one male paratype in my collection (JMC). Dimensions are given in mm. Brailovsky $(1980)^{3}$ published excellent photographs of the microtomines oceurring in Mexico.

\section{DISCUSSION}

Homalocoris punctatus Maldonado n. sp.

(Figs. 1-7)

Male - head, pronotum, scutellum black. Head granulations stramineous; above and below behind eye with small stramineous area; collum black; antennophore black. First antennal segment light brown, apex and base narrowly brown; antennophore black; second segment mostly brown, first and last pseudosegments black; third and fourth segments blackish. Beak black, first segment with apical half brown. Pronotum granulations along lateral margins of anterior lobe and on basal half of lateral margins of posterior lobe stramineous, granulations black on apical half; posterior lobe with 6 or 8 stramineous spots (fig. 6); meso- and metopleurae brownish, granulations stramineous; pronotum laterally

${ }^{1}$ Manuseript submitted to Editorial Board May 15, 1986.

Ponce School of Medicine, Box 7004, Ponce, P. R. 00732, and Department of Plant. Protection, U. P. R., Mayaguiez, P. R. 00708. The author thanks Dr. T. J. Henry, NMNH, Washington, D. C., for the loan of this material.

" Brailovsky, H. 1908. Hemiptera-Heteroptera de México. V. Revisión de la Subfamilia Mierotominae (Reduviidae). An. Inst. Biol. Univ. Nac, Autón. México. 5 (Zool) (1): 113-22. 

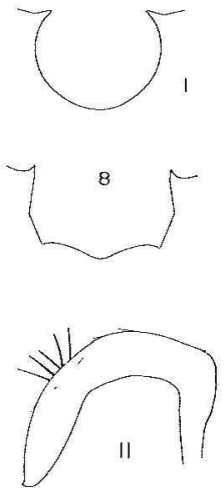

7

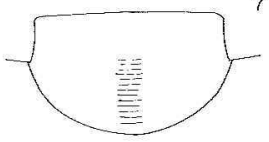

12

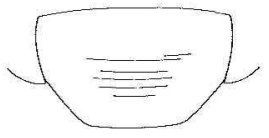

9

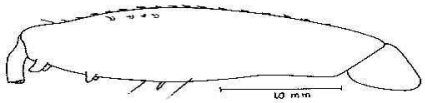

10
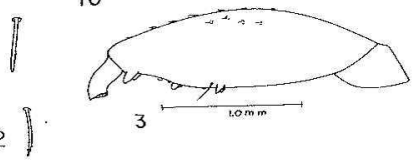

3
4

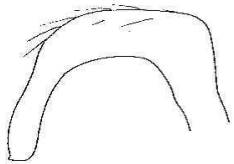

5

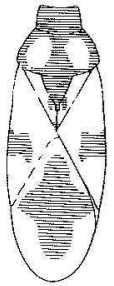

14

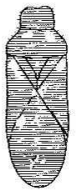

13

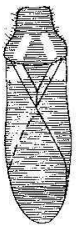

15

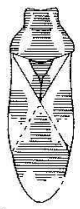

16

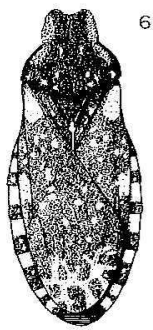

Plate 1.-Homalocoris punctatus n. sp.-Male-1. dorsal opening of hypopygium; 2. setae on radial vein; 3 . metafemur; 4. left clasper, dorsal; 5 . claw; 6 . pronotum, hemelytra, and connexivum,-Female,-7, eighth tergum, dorsal. Homalocoris varius (Perty). Male. -8. dorsal opening of hypopygium; 9 . setae on radial vein; 10 . metafemur; 11. left clasper, dorsal.-Female.-12. eighth tergum, dorsal. Homalocoris binotatus Champion.13. color pattern, dorsal, Homalocoris guttatus (Walker).-14. color pattern, dorsal. Homalocoris maculicollis Stal,-15, color pattern, dorsal. Homalocoris minutus Mayr.16. color pattern, dorsal. 
with blackish granulations. Thoracic sterna black, prosternum with stramineous granulations, meso- and metasternum with black granulations. Femora stramineous, with three poorly defined broad brown annuli because setae, granulations, and stramineous spots blurr their boundaries; tibiae stramineous, first with 4 , middle with 3 , and hind with basal and apical annuli. Connexival segments with basal half or third stramineous, apical half or $2 / 3$ black, black areas with 1 or 2 stramineous spots. Abdominal sterna blackish brown, inconspicuously and irregularly spotted with stramineous. Forewings brown, with 3 stramineous areas; basally, preapically on embolium, and at the end of the cells of membrane; clavus, corium, and membrane irregularly spotted with stramineous (fig. 6). Body with moderately abundant, long, fine decumbent stramineous setae arising from granules.

Head granulose, juga extending beyond apex of tylus; from anterior margin of eye to apex of antennophore 0.15 , from same to apex of jugum 0.46 , width across eyes 1.55 , interocular space 0.6 , from interocular suture to apex of jugum 0.8 , from same to postocular constriction 0.45 . Antenna: I, 0.35; II, 1.55; III, 0.85; IV, 0.96; first segment barrel-shaped, glabrous; II subdivided into 7 pseudosegments; setae long and scattered on II; III and IV moderately abundant long pilose. Beak thick, segments: I, 0.55; II, 0.45; III, 0.3. Femora granulose; first two strongly thickened, hind linear; length and greatest thickness: $1.8 \times 0.55,1.6 \times 0.56,2.25$ $\times 0.5$; all with preapical ventral spines (fig. 3 ); first and second with increasingly thicker setae from base to first spine. First and second tibiae with small fossula on truncate apex; strong semidecumbent setae facing tibiae; hind tibia fine setose; without fossula. Tarsal segments increasingly longer, third over twice as long as first; claws as in figure 5. Pronotum strongly and abundantly granulose, granules on posterior lobe aligned longitudinally and not setose; anterior lobe with deep median furrow, dise with 4 diverging rows of a few granules and smooth areas between rows; anterior lobe length 0.7 , width 1.4 ; posterior lobe length 1.0 , width 2.45 , humeral angles angular, not produced. Scutellum width 1.15 , length 0.6 ; disc transversely corrugate and sparsely granulose, apex 2-pronged, prongs apart at about their width. Forewings slightly surpassing apex of abdomen; setae on radial vein relatively thick, truncate, and with microspines (fig. 2); similar setae externally on hypopygial capsule. Genitalia - opening of genital capsule semi-circular (fig. 1), claspers thinner on apical third (fig. 4). Length to apex of wings 8.2 , width across abdomen 3.22.

Female - coloration as in male. Head - from anterior margin of eye to apex of antennophore 0.15 , from same to apex of jugum 0.45 , width across eyes 1.6 , interocular space 0.6 , from interocular suture to apex of jugum 0.75 , from suture to postocular constriction 0.5. Antennae: I, 0.3; 
II, 1.56; III, 0.9; IV, 0.95; shape and pilosity as in male. Beak: shape as in male; I, 0.55; II, 0.6; III, 0.5. Femora as in male, length and greatest thickness: $1.75 \times 0.6,1.65 \times 0.6,2.44 \times 0.5$. Tibiae and tarsal segments as in male. Scutellum shaped as in male, length 0.6, width 1.2. Pronotum - shape and granulation as in male; anterior length 0.72 , width 1.45; posterior lobe length 1.3, width 2.36. Forewings reaching to before apex of 7 th tergum; eighth tergum semi-circular (fig. 7), transversely corrugate medianly, inserted anterior to its mid-length into 7th tergum. Overall body length 8.6 , width 3.4 .

Holotype - male, BRAZIL, Nova Teutonia, Sta. Catarina, vii-311944, F. Plauman collector, Lutz collection, in NMNH. Allotype - female, same data. Paratypes 2 females, 2 males, same data, in NMNH; one male in JMC, same data.

H. punctatus is closer to $H$. varius and differ by the characters in the key. See under $H$. varius for additional details to separate these species.

\section{Homaloconis binotatus Champion}

Known from Guatemala and Nicaragua. Color pattern as in figure 13. Length 14.5-15.5.

\section{Homalocoris guttatus (Walker)}

Known from Mexico. Color pattern as in figure 14. Length 11.0-12.0.

\section{Homalocoris maculicollis Stål}

Known from Mexico, Ecuador, Guatemala, Arizona (USA). Color pattern as in figure 15. Length 11-12.

\section{Homalocoris minutus Mayr}

Known from Arizona (USA). Color pattern as in figure 16. Body and appendages long pilose, more abundant and longer than in the other species. Length 7-11.

\section{Homalocoris varius (Perty)}

(Figs. 8-12)

Known from Argentina, Bolivia, Brazil, British Honduras, Colombia, El Salvador, Costa Rica, Guatemala, Mexico, Panama, and Venezuela. The following characteristics separate this species from $H$. punctatus: without stramineous spots, hemelytra with 3 stramineous areas as in $H$. punctatus; setae on radial vein and hypopygial capsule fine and tapering to a sharp point (fig. 9), upper opening of hypopygial capsule quadrangular (fig. 8); hind femur longer, thinner (fig. 10); claspers not thinner on apical third and without stout setae ventrally at about midlength (fig. 11), female with 8th tergum trapezoidal (fig. 12), inserted to about $2 / 3$ 
its length into 7 th. Some specimens from Brazil and Panama have the light color areas whitish instead of stramineous.

Key to the species of Homalocoris

1. Legs stramineous, annulate with dark brown; apex of scutellum 2pronged; forewing variegate; second antennal segment with 7-8 pseudosegments

Legs black; apex of scutellum single, truncate; forewings black, with stramineous or red areas or stramineous with black areas ...... 3

2. Stramineous spots on pronotum, clavus, corium, membrane, and black areas of connexival segments; I antennal segment stramineous, basally and apically brown ........................... $H$. punctatus $\mathrm{n} . \mathrm{sp}$.

Without stramineous spots; I antennal segment unicolorous . H. varius

3. Corium stramineous with median black area ....................... 4

Corium black with stramineous or red areas ....................... 5

4. Pronotum with $1+1$ stramineous oval vittae on posterior lobe only; black vitta on corium subquadrate; over $14 \mathrm{~mm}$..... H. binotatus

Pronotum with $1+1$ stramineous elongate vittae extended into both lobes; black vitta on corium oblong; under $12 \mathrm{~mm}$. H. maculicollis 5. Posterior lobe of pronotum anteriorly with $1+1$ stramineous spots; hemelytra at rest with 5 small stramineous spots; short pilose

H. guttatus

Posterior lobe of pronotum with $1+1$ elongate reddish areas; base of clavus and corium reddish; long pilose ............... H. minutus

\section{RESUMEN}

Homalocaris puncfafus sp. nov. y clave a las especies del género Reduviidae, Microtominae.

Homalocoris punctatus sp. nov. se describe de Brasil; se ilustra y compara con sus congéneres. Se provee una clave para separar las seis especies que contiene el género. 
